\title{
CUSTOMERS' PERCEPTION TOWARDS MOBILE BANKING SERVICES WITH SPECIAL REFERENCE TO DEHRADUN DISTRICT OF UTTARAKHAND: A CRITICAL ANALYSIS
}

\section{RAVI PRASAD \& DR JITENDRA SINGH}

Research Scholar, (Management), Uttaranchal University, Dehradun, Uttarakhand, India

Associate Professor, (HOD) Management, Uttaranchal University, Dehradun, Uttarakhand, India

\begin{abstract}
The banking sectors have to adopt the modern technology to provide effective banking services to its customers. It plays a vital role in the economic development of the region in the area of its operation. This paper focuses on the importance of mobile banking services and its awareness among the rural customers in the Dehradun District of Uttarakhand.In this study, the researcher has selected 250 respondents who are aware of the modern technology and use mobile banking services. It aims to understand the perception and customer satisfaction of mobile banking services among rural banking customers. The research is descriptive in nature. The study uses pre-structured questionnaire for survey using non-probability sampling. The study attempts to understand the benefits and limitations of mobile banking with special reference to Dehradun District among the rural bank customers availing mobile banking services. With increasing demand from the consumers for effective mobile banking services, the rural banks have been constantly thinking of innovative customized services to remain competitive in the market. The preference of the rural bank customers is clearly evident as various electronic channels like ATM's, mobile banking and internet banking has entirely changed the perception of people towards banking services provided by banks in the market. The mobile banking service is spreading like a virus among the rural customers due to its advantages and also due to increase in the number of mobile subscribers in the rural areas. The researcher has analyzed the data collected from the respondents with the help of percentage \& interpreted the various figures to arrive at the conclusion of the paper. Further, it attempts to educate rural banks to promote the awareness level among the rural customers about mobile banking services through a financial literacy campaign in the District for their customers.

KEYWORDS: Mobile Banking Services, Customers, Rural Bank and Digital Technology
\end{abstract}

Received: Jun 08, 2020; Accepted: Jun 28, 2020; Published: Sep 08, 2020; Paper Id.: IJMPERDJUN20201116

\section{INTRODUCTION}

Cell phones are the only device people bring, and service beyond voice and text messaging is booming around the globe. The key reason mobile banking scores over internet banking is that now it helps customers with 'Anywhere Banking' to access their banks without using a computer terminal. Now they can do it on the go when they're waiting for their bus to get to work, when they're traveling, or when they're waiting for their orders to get through the restaurant. Mobile banking supports services like Minimum balance alert, Account statement inquiry, bill payment alert, fund transfer between accounts, account balance inquiry, debit/credit card alerts, recent bank transaction details, cheque book request, and cheque status inquiry. Eventually, technology opened up possibilities for various distribution networks. Technology-aided items such as ATMs, point of sale systems, anywhere banking, smart cards and internet banking have offered consumers the ability to select their platform to suit their 
needs, and bank would also have channel-based customer service approaches. Technology has brought about a sea shift in the operation of banks over the years. Therefore, banks with mobile technology will give their customers a wide range of services such as making funds transfer, online shopping of goods and services accessing account information etc. It is referred to as mobile banking or M-banking. Mobile banking means that all facilities are delivered to users by bankers through a cell phone. It includes transfers of funds, payment of bills, various inquiries, checking account statement and balances, transfer of money, verification of different accounts, enquiry on the automatic transmission system balances, SMS services, etc. This study sought to know the pros and cons of mobile banking services for rural customers in the uttarakhand district of Dehradun.

\section{REVIEW OF LITERATURE}

Wessels \& Drennan (2010) The paper found that percepted value, perceived risk, costs and usability are the major reasons influencing consumers' accepting of mobile banking services provided by banks in its empirical study using a national Web-based survey among 553 banking clients.

Vijay m. kumbhar (August, 2011) The study reveals that, given this huge potential, banks and consumers face a range of obstacles and threats to take advantage of the mobile banking system. Poor network coverage, security issues, low cost performance, difficulties in using cell phones due to service deficiencies and low IT literacy as key factors that contribute to the low or poor adoption of mobile banking services in rural India.

Chauhan, (2012). This paper examines the numerous problems posed by Mobile banking and shows that there is a need for understanding among mobile banking users. More and more users are going to be connected.

Mishra \& Sahoo, (2013). Mobile banking is one of the alternative channels for fast and efficient service to customers, anytime or anywhere. It also discusses the advantages \& benefits of mobile banking to customers.

Vidyapriya. P. and Mohanasundari. M, (2015). Indian banks have leveraged technology effectively and introduced a variety of conventional product variants and modern e-based services. Although ATM is popular with cash withdraws, there is sub- optimum use of other services such as mobile banking and Internet banking. The whole spectrum of services offered in ATMs still does not extend to customers.

\section{STATEMENT OF THE PROBLEM}

In the current situation, the banking Industry has seen considerable progress and success with regard to mobile banking services and its innovative products. The growth has turned out in the growing number of mobile banking transactions for bank customers, which are faster and more convenient mode of transaction. Banking sector is one of the industries which have taken advantage of information technology's programs to help with banking transactions and to expand banking facilities and opportunities for its clients. Mobile banking services have allowed millions of consumers to carry out their transactions at any time, anytime, conveniently, rapidly and seamlessly with perfections. However, in order to carry out banking transactions on the mobile phone, it is necessary to have some basic knowledge about the use of the Internet which, to some extent, limits the number of rural customers willing to use mobile banking facilities. Many people in the rural areas who are not comfortable with Android phone find it difficult to use mobile banking services. 


\section{OBJECTIVE OF THE STUDY}

- To study the benefits of mobile banking service among rural people in Dehradun District of Uttarakhand.

- To analyze the factors influencing the awareness level and usage of mobile banking services among the rural bank customers in Dehradun District of Uttarakhand.

- To examine the satisfaction level of the rural bank customers towards the mobile banking services.

\section{SCOPE OF THE STUDY}

This research offers a roadmap to the present framework of mobile banking services and examines the awareness of rural customers in the Dehradun District using mobile banking services. This study helps in understanding the rural customer's experience and comfort with and working of mobile banking through emerging technology. This also helps to consider the variety of options available in mobile banking. Ultimately, this will allow the consumers as well as the banking sector to realize the value of mobile banking.

\section{RESEARCH METHODOLOGY}

\section{Research Design}

Data are collected for study purposes in two forms, one primary and the other secondary. The data collected was divided into two main categories-primary and secondary data. Primary data were collected through exploratory research such as customer and non-customer questionnaires. Secondary data was obtained from blogs, publications, journals and magazines as well as academic papers.

\section{Type of Study and Data}

The current study has used convenience sampling method in collection of data from the rural customers in Dehradun District. The data used is both primary and secondary. Relevant studies, RBI monthly newsletters, journals, newspapers, business newspapers, books and posts, e-media and other open literature are secondary sources for this study. A standardized questionnaire is used to test the understanding, perception and satisfaction level of rural customers towards mobile banking services. Primary data was obtained from 250 mobile banking customers in the Dehradun district of uttarakhand via a separate pre-tested questionnaire. Mobile banking users have been randomly selected from the Dehradun district of Uttarakhand..

\section{Tools for Analysis}

The data collected was collected and analyzed with the help of a percentage \& interpreted by means of different figures. Thus, Statistical tools used by the researcher to carry out the study are only in percentage analysis \& Hypothesis analysis.

\section{LIMITATION OF THE STUDY}

This study is not infinite. Some of this study's key drawbacks are outlined as follows:

- Lacking rural respondents' proper cooperation.

- Poor contact with clients of rural banks.

- Intimelessness.

- Respondents reacted biasedly. 
This study covers limited areas and the sample size was also limited to 250 rural customers in the district of Dehradun. Further studies of a larger sample size should be performed so that findings could be generalized.

\section{Mobile Banking System Concept}

Mobile banking is an electronic system delivering several basic services via Smartphone. Mobile banking is a feature that is introduced by a bank or a financial institution that allows its clients to carry out financial or banking transactions by using their smart phone or laptops. Mobile banking allows the smart phones or other devices to perform online banking transactions away from your computer, laptop or other gadgets, such as money transfer from one account to another, payment of electricity bills, payment of gas bills, telephone charging, online shopping, etc.

\section{BENEFITS OF MOBILE BANKING SERVICES}

\section{Convenience}

Mobile banking is definitely more convenient than calling or physically visiting a bank. Financial transactions can be carried out at any moment; day or night and on holidays.

\section{Security}

Mobile banking is very safe, risk-free and reliable when it comes to mobile pin (m-pin). Mobile banking authentication lets you track your own bank account balance and transaction history effectively. It does not allow access to unauthorized users.

\section{Speed}

Consumers make their banking transaction in a fraction of a second via mobile with the aid of $4 \mathrm{G}$ technology. Customers can save precious time and transportation expenses to enter the bank for their financial transactions.

\section{Cheaper}

Mobile banking is much cheaper or cost-effective, as these services are offered by banks at reduced cost or free of charge to consumers.

\section{Save Times}

Mobile banking will save a lot of time.

\section{Economic Growth}

People which have no bank account but with the aid or reference of mobile banking awareness, particularly the young generation, the bank account will be opened in any bank and will contribute to economic growth.

\section{Problems Related to Rural Mobile Banking Services}

The rural clients in Dehradun District have issues with mobile banking. The problems faced by the customers in the rural areas are as follows:

- Unaware of the integrity of transactions

- Mobile security:

- The availability of the network 

of Uttarakhand: A Critical Analysis

- High transaction costs

- e-mail and network access

- Literacy of rural people

- Unconscious of new innovation

- The capacity of the phone to work

- Inadequate guidance

- Identity theft

\section{ANALYSIS AND INTERPRETATION}

Table 1: Socio- Economic Profile of Mobile Banking Customers, Dehradun

\begin{tabular}{|c|c|c|c|}
\hline S. No & Particulars & Frequency & Percent (\%) \\
\hline 1 & Male & 162 & 65 \\
\hline 2 & Female & 88 & 35 \\
\hline & Total & 250 & 100 \\
\hline \multicolumn{4}{|c|}{ Age (years) } \\
\hline 1 & Below 25 & 28 & 11 \\
\hline 2 & $25-35$ & 65 & 26 \\
\hline 3 & $35-45$ & 94 & 38 \\
\hline 4 & $45-55$ & 47 & 19 \\
\hline 5 & Above 55 & 16 & 06 \\
\hline \multicolumn{2}{|r|}{ Total } & 250 & 100 \\
\hline \multicolumn{4}{|c|}{ Education } \\
\hline 1 & High School & 25 & 10 \\
\hline 2 & Intermediate & 50 & 20 \\
\hline 3 & Graduation & 120 & 48 \\
\hline 4 & Post Graduation & 55 & 22 \\
\hline \multicolumn{2}{|r|}{ Total } & 250 & 100 \\
\hline \multicolumn{4}{|c|}{ Profession } \\
\hline 1 & Agriculturist & 24 & 9 \\
\hline 2 & Business man & 45 & 18 \\
\hline 3 & Professional & 42 & 17 \\
\hline 4 & Employee in Public sector & 44 & 18 \\
\hline 5 & Employee in Private sector & 70 & 28 \\
\hline 6 & Students & 25 & 10 \\
\hline \multicolumn{2}{|r|}{ Total } & 250 & 100 \\
\hline \multicolumn{4}{|c|}{ Monthly Income } \\
\hline 1 & Below 50,000 & 25 & 10 \\
\hline 2 & $50,000-1,00,000$ & 62 & 25 \\
\hline 3 & $1,00,000-2,00,000$ & 77 & 31 \\
\hline 4 & $2,00,000-3,00,000$ & 36 & 14 \\
\hline 5 & $3,00,000$ and Above & 50 & 20 \\
\hline \multicolumn{2}{|r|}{ Total } & 250 & 100 \\
\hline \multicolumn{4}{|c|}{ Types of Account } \\
\hline 1 & Saving Account & 159 & 64 \\
\hline 2 & Current Account & 91 & 36 \\
\hline \multicolumn{2}{|r|}{ Total } & 250 & 100 \\
\hline \multicolumn{4}{|c|}{ Marital Status } \\
\hline 1 & Single & 149 & 60 \\
\hline 2 & Married & 101 & 40 \\
\hline \multicolumn{2}{|r|}{ Total } & 250 & 100 \\
\hline \multicolumn{4}{|c|}{ Family members } \\
\hline 1 & Up to 2 & 148 & 59 \\
\hline
\end{tabular}




\begin{tabular}{|c|c|c|c|}
\hline 2 & 2 to 4 & 68 & 27 \\
\hline 3 & 4 and Above & 34 & 14 \\
\hline \multicolumn{2}{|c|}{ Total } & $\mathbf{2 5 0}$ & $\mathbf{1 0 0}$ \\
\hline
\end{tabular}

\section{Source: Survey Result}

The above table-1 shows the socio-economic profile of mobile banking services at Dehradun District of Uttarakhand.38\% of the customers in the age group of 35-45 use mobile banking services. Out of which $65 \%$ are males. It is also clear that $48 \%$ of the graduates use mobile banking services. $28 \%$ of the customer using Mobile banking services work in private sectors. $31 \%$ users of Mobile banking services is from the middle income level group. Majority of Mobile banking services users are single at $60 \%$ \& $64 \%$ of saving account-holders use Mobile services.

Table 2: Awareness Level of Mobile Banking Services of Rural Bank Customers, Dehradun

\begin{tabular}{|c|l|c|c|}
\hline S. No & Awareness of Mobile Banking Services & No of Respondents & Percentage of Respondents \\
\hline 1 & Newspaper Advertisement & 60 & 24 \\
\hline 2 & Advertisements in Television & 40 & 16 \\
\hline 3 & Bank Officials & 90 & 36 \\
\hline 4 & Friends and Relatives & 60 & 24 \\
\hline \multicolumn{2}{|c|}{ Total } & $\mathbf{2 5 0}$ & $\mathbf{1 0 0}$ \\
\hline
\end{tabular}

\section{Source: Survey Result}

Table 2 indicates awareness level of Mobile banking Services of rural bank customers in the District of Dehradun. It reveals that $36 \%$ of the respondents are aware of Mobile banking services from the Bank officials and it also shows that $24 \%$ of the respondents were aware about mobile banking services from Newspaper advertisement and through friends and relatives. $16 \%$ of the customers become aware of the mobile banking services through advertisement in Newspaper. It shows that bank officials are creating maximum awareness level of the services among of the customers in the District of Dehradun.

Table 3: Benefits of Mobile Banking System for the Rural Customers

\begin{tabular}{|c|c|c|c|c|c|c|c|c|c|c|c|}
\hline \multirow[b]{2}{*}{ S.No } & \multirow{2}{*}{$\begin{array}{c}\text { Mobile banking } \\
\text { Benefits }\end{array}$} & \multicolumn{2}{|c|}{ S.A. } & \multicolumn{2}{|r|}{ A } & \multicolumn{2}{|r|}{$\mathbf{N}$} & \multicolumn{2}{|r|}{ D } & \multicolumn{2}{|c|}{ SD } \\
\hline & & No & $\begin{array}{c}\text { Percent } \\
(\%)\end{array}$ & No & $\begin{array}{c}\text { Percent } \\
(\%)\end{array}$ & No & $\begin{array}{c}\text { Percent } \\
(\%)\end{array}$ & No & $\begin{array}{c}\text { Percent } \\
(\%)\end{array}$ & No & $\begin{array}{c}\text { Percent } \\
(\%)\end{array}$ \\
\hline 1 & Time Saving & 230 & 92 & 20 & 8 & - & - & - & - & - & - \\
\hline 2 & Easy Accessibility & 180 & 72 & 50 & 20 & 8 & & - & - & - & - \\
\hline 3 & Any time banking & 220 & 88 & 20 & 8 & 10 & 4 & - & - & -- & - \\
\hline 4 & Any where banking & 230 & 92 & 20 & 8 & - & - & - & - & - & - \\
\hline 5 & No Queue & 140 & 56 & 110 & 44 & - & - & - & - & - & - \\
\hline 6 & Easy Monitoring & 30 & 12 & 200 & 80 & 20 & 8 & & - & - & - \\
\hline 7 & Quick Settlement & 90 & 36 & 110 & 44 & 50 & 20 & & - & - & - \\
\hline 8 & $\begin{array}{l}\text { Secured } \\
\text { transactions }\end{array}$ & 80 & 32 & 90 & 36 & 80 & 32 & - & - & - & - \\
\hline
\end{tabular}

Note: S.A. Strongly Agree;A. Agree;N.Neutral; D. Disagree;S.D.Strongly Disagree

Source: Survey Result

Table 3 demonstrates mobile banking system advantages for rural customers. The table indicates that 92 percent of participants strongly agree with the benefits of time-saving; 72 percent of respondents strongly agree with the benefits of simple accessibility; 88 percent of respondents strongly agree on the benefits of banks at all times;92 percent of respondents strongly agree with the benefits of anywhere in the banking sector;56 percent of respondents strongly agree It is observed that maximum respondents profit from time-saving mobile banking services 
Table 4: Factors Influencing Mobile Banking Facility for the Rural Customers, Dehradun

\begin{tabular}{|c|l|c|c|c|c|c|c|c|c|c|c|}
\hline \multirow{2}{*}{ S.No } & \multirow{2}{*}{ Description } & \multicolumn{2}{|c|}{$\begin{array}{c}\text { Strongly } \\
\text { Agree }\end{array}$} & \multicolumn{2}{|c|}{ Agree } & \multicolumn{2}{c|}{ Neutral } & \multicolumn{3}{c|}{ Disagree } & $\begin{array}{c}\text { Strongly } \\
\text { Disagree }\end{array}$ \\
\cline { 3 - 12 } & & No & $\begin{array}{c}\text { Percent } \\
(\boldsymbol{\%})\end{array}$ & No & $\begin{array}{c}\text { Percent } \\
(\boldsymbol{\%})\end{array}$ & No & $\begin{array}{c}\text { Percent } \\
(\%)\end{array}$ & No & $\begin{array}{c}\text { Percent } \\
(\%)\end{array}$ & $\begin{array}{c}\text { No } \\
\text { Nercent } \\
(\%)\end{array}$ \\
\hline 1 & Convenience & 200 & 80 & 50 & 20 & - & - & - & - & - & - \\
\hline 2 & Quality of service & 180 & 72 & 40 & 16 & 20 & 10 & 10 & 04 & - & - \\
\hline 3 & Friends Advice & 160 & 64 & 40 & 16 & 30 & 12 & 20 & 8 & - & - \\
\hline 4 & Trust & 140 & 56 & 60 & 24 & 50 & 20 & - & - & - & - \\
\hline 5 & Location & 170 & 68 & 50 & 20 & 15 & 6 & 15 & 6 & - & - \\
\hline
\end{tabular}

Source: Survey Result

Table 4 shows the factors affecting mobile banking facilities for rural customers, Dehradun. It shows that 80 percent of respondents strongly agree with the affecting convenience factor; 72 percent of respondents strongly agree with the service quality factor; 64 percent of respondents strongly agree with the friend counseling factor; 56 percent of respondents strongly agree with the service quality factor; Clearly most respondents are motivated by convenience variables.

Table 5: Purpose for Using Mobile Banking Services for the Rural Customers, Dehradun

\begin{tabular}{|c|c|c|c|c|c|c|c|c|c|c|c|}
\hline \multirow{2}{*}{$\begin{array}{l}\text { S. } \\
\text { No }\end{array}$} & \multirow{2}{*}{ Description } & \multicolumn{2}{|c|}{ Strongly Agree } & \multicolumn{2}{|c|}{ Agree } & \multicolumn{2}{|c|}{ Neutral } & \multicolumn{2}{|c|}{ Disagree } & \multicolumn{2}{|c|}{$\begin{array}{l}\text { Strongly } \\
\text { Disagree }\end{array}$} \\
\hline & & No & $\begin{array}{c}\text { Percent } \\
(\%)\end{array}$ & No & $\begin{array}{c}\text { Percent } \\
(\%)\end{array}$ & No & $\begin{array}{c}\text { Percent } \\
(\%)\end{array}$ & No & $\begin{array}{c}\text { Percent } \\
(\%)\end{array}$ & No & $\begin{array}{l}\text { Perce } \\
\text { nt }(\%)\end{array}$ \\
\hline 1 & $\begin{array}{l}\text { Online bill } \\
\text { payment }\end{array}$ & 160 & 64 & 40 & 16 & 30 & 12 & 20 & 8 & - & - \\
\hline 2 & $\begin{array}{l}\text { Funds } \\
\text { Transfer }\end{array}$ & 200 & 80 & 15 & 6 & 15 & 6 & 20 & 8 & - & - \\
\hline 3 & $\begin{array}{l}\text { Balance } \\
\text { Inquiry }\end{array}$ & 90 & 36 & 110 & 44 & 40 & 16 & 10 & 4 & - & - \\
\hline 4 & $\begin{array}{l}\text { Online } \\
\text { Shopping }\end{array}$ & 60 & 24 & 97 & 39 & 43 & 17 & 50 & 20 & - & - \\
\hline 5 & $\begin{array}{l}\text { Online } \\
\text { banking } \\
\text { Transactions }\end{array}$ & 100 & 40 & 75 & 30 & 55 & 22 & 20 & 8 & - & - \\
\hline
\end{tabular}

Source: Survey Result

Table 5 shows the intention of using Mobile Banking Services for rural customers, Dehradun. It shows that $64 \%$ of respondents use mobile banking services for online bill payment; $80 \%$ of respondents use mobile banking services for funds transfer; $44 \%$ for balance inquiry; $39 \%$ for online shopping; $40 \%$ for online banking transactions. Maximum respondents use mobile banking services to pay online bills and transfer funds.

Table 6: Usage of Mobile Banking Services for the Rural Customers, Dehradun

\begin{tabular}{|c|c|c|c|c|c|c|c|c|c|c|c|}
\hline \multirow{2}{*}{$\begin{array}{c}\text { S.N } \\
0\end{array}$} & \multirow{2}{*}{ Particulars } & \multicolumn{2}{|c|}{ Strongly Agree } & \multicolumn{2}{|c|}{ Agree } & \multicolumn{2}{|c|}{ Neutral } & \multicolumn{2}{|c|}{ Disagree } & \multicolumn{2}{|c|}{$\begin{array}{l}\text { Strongly } \\
\text { Disagree }\end{array}$} \\
\hline & & No & $\begin{array}{c}\text { Percent } \\
(\%)\end{array}$ & No & $\begin{array}{c}\text { Percen } \\
t(\%)\end{array}$ & No & $\begin{array}{c}\text { Percent } \\
(\%)\end{array}$ & No & $\begin{array}{c}\text { Percent } \\
(\%)\end{array}$ & No & $\begin{array}{c}\text { Percen } \\
\text { t }(\%)\end{array}$ \\
\hline 1 & $\begin{array}{l}\text { Secured } \\
\text { Transaction }\end{array}$ & - & - & 40 & 16 & 50 & 20 & 90 & 36 & 70 & 28 \\
\hline 2 & $\begin{array}{l}\text { Quick } \\
\text { Settlement }\end{array}$ & 100 & 40 & 140 & 56 & 10 & 4 & - & - & - & - \\
\hline 3 & Fund Transfer & 60 & 24 & 130 & 52 & 30 & 12 & 30 & 12 & - & - \\
\hline
\end{tabular}




\begin{tabular}{|c|l|c|c|c|c|c|c|c|c|c|c|}
\hline 4 & $\begin{array}{l}\text { E- Payment } \\
\text { System }\end{array}$ & 80 & 32 & 140 & 56 & 15 & 6 & 15 & 6 & - & - \\
\hline 5 & NEFT/RTGS & 50 & 20 & 110 & 44 & 40 & 16 & 30 & 12 & 20 & 8 \\
\hline 6 & $\begin{array}{l}\text { Core banking } \\
\text { system }\end{array}$ & 20 & 8 & 60 & 24 & 40 & 16 & 80 & 2 & 50 & 20 \\
\hline
\end{tabular}

Source: Survey Result

Table 6 indicates the usage of mobile banking services for rural customers. $36 \%$ of respondents disagree with the use of safe transactions; $56 \%$ of respondents agree with the use of rapid settlement; $52 \%$ agree with the use of electronic funds transfer; $56 \%$ agree with the use of electronic funds. It is concluded that maximum respondents agreed using quick settlement and electronic payment system.

Table 7: Frequency of Mobile Banking Transactions by Rural Bank Customers, Dehradun

\begin{tabular}{|c|l|c|c|}
\hline S.No & \multicolumn{1}{|c|}{ Particulars } & Respondents & Percent (\%) \\
\hline 1 & Occasionally & 60 & 24 \\
\hline 2 & Regularly & 160 & 64 \\
\hline 3 & Never & 10 & 4 \\
\hline 4 & Very often & 20 & 8 \\
\hline \multicolumn{2}{r|}{ Total } & $\mathbf{2 5 0}$ & $\mathbf{1 0 0}$ \\
\hline
\end{tabular}

Source: Survey Result

Table 7 above indicates the frequency of Mobile banking transactions by rural bank customers the District of Dehradun. It indicates that $24 \%$ of the participants use mobile banking services occasionally; $64 \%$ of the respondents frequently use of mobile banking services; $4 \%$ of the respondents never use mobile banking services; and $8 \%$ of the respondents very often to use mobile banking services. It is observed that the frequency of mobile banking services has increased among the rural bank customers in Dehradun.

Table 8: Rural Bank Customer's Opinion About Mobile Banking Services, Dehradun

\begin{tabular}{|c|l|c|c|}
\hline S.No & \multicolumn{1}{|c|}{ Category } & Respondents & Percentage (\%) \\
\hline 1 & Simple to operate & 110 & 44 \\
\hline 2 & Easy to use the applications & 40 & 16 \\
\hline 3 & Difficulty in operating the banking services & 50 & 20 \\
\hline 4 & Training needed for Usage & 50 & 20 \\
\hline \multicolumn{2}{|c|}{ Total } & $\mathbf{2 5 0}$ & $\mathbf{1 0 0}$ \\
\hline
\end{tabular}

Source: Survey Result

Table 8 indicates the rural bank customer's opinion about Mobile banking services in Dehradun. The table shows that out of 250 respondents, $44 \%$ respondents have felt that it is simple to operate; $16 \%$ of the respondents felt that it is easy to use the application of mobile banking services;20\% of the respondents felt that there is difficulty in operating the banking services and training is needed for using the mobile banking services among the rural customers in Dehradun District. It is clear for the above table that mobile banking services have increased and rural customers felt it is simple to operate. 
Table 9: Satisfaction Level of Rural Bank Customers about Mobile Banking Services, Dehradun

\begin{tabular}{|c|c|c|c|c|c|c|c|c|c|c|c|}
\hline \multirow{2}{*}{$\begin{array}{l}\text { S. } \\
\text { No }\end{array}$} & \multirow{2}{*}{ Category } & \multicolumn{2}{|c|}{$\begin{array}{c}\text { Strongly } \\
\text { Agree }\end{array}$} & \multicolumn{2}{|c|}{ Agree } & \multicolumn{2}{|c|}{ Neutral } & \multicolumn{2}{|c|}{ Disagree } & \multicolumn{2}{|c|}{$\begin{array}{l}\text { Strongly } \\
\text { Disagree }\end{array}$} \\
\hline & & No & $\begin{array}{c}\text { Percent } \\
(\%)\end{array}$ & No & $\begin{array}{c}\text { Percent } \\
(\%)\end{array}$ & No & $\begin{array}{c}\text { Percent } \\
(\%)\end{array}$ & No & $\begin{array}{c}\text { Percent } \\
(\%)\end{array}$ & No & $\begin{array}{c}\text { Percent } \\
(\%)\end{array}$ \\
\hline 1 & Highly Satisfied & 50 & 20 & 125 & 50 & 50 & 20 & 25 & 10 & - & - \\
\hline 2 & Satisfied & 100 & 40 & 140 & 56 & 10 & 4 & - & - & - & - \\
\hline 3 & Average & 60 & 24 & 80 & 32 & 100 & 40 & - & - & - & - \\
\hline 4 & Dissatisfied & - & - & - & - & - & - & - & - & - & - \\
\hline 5 & Highly dissatisfied & - & - & - & - & - & - & - & - & - & - \\
\hline
\end{tabular}

\section{Source: Survey Result}

Table 9 indicates the satisfaction Level of rural bank customers about Mobile banking Services in Dehradun. The table shows that out of 250 respondent,50\% of the respondents are highly satisfied with the mobile banking services; $56 \%$ of the respondents are satisfied with the mobile banking services provided by rural banks in the dehradun district of Uttarakhand;32\% of the respondents felt that the mobile banking services are average. None of the respondents were dissatisfied or highly dissatisfied with the mobile banking services in Dehradun District. The table above indicates most respondents are satisfied with mobile banking services.

Table 10: Problems Faced in Usage of Mobile Banking Services by Rural Customers, Dehradun

\begin{tabular}{|c|l|c|c|}
\hline S.No & \multicolumn{1}{|c|}{ Category } & No of Respondents & Percentage (\%) \\
\hline 1 & Internet connectivity speed & 100 & 40 \\
\hline 2 & Technical Problems & 70 & 28 \\
\hline 3 & Security risk & 50 & 20 \\
\hline 4 & Malware & 30 & 12 \\
\hline \multicolumn{2}{|c|}{ Total } & $\mathbf{2 5 0}$ & $\mathbf{1 0 0}$ \\
\hline
\end{tabular}

Source: Survey Result

Table 10 above shows the problems faced in usage of Mobile banking Services by rural customers in Dehradun.The following are the problems faced by the respondents: $40 \%$-Internet connectivity speed,28\%- technical problems, $10 \%$ - security risk, $12 \%$ - Malware. It is concluded that maximum respondents face the problem of internet connectivity speed in the rural areas.

\section{TESTING OF HYPOTHESIS}

\section{Chi square Test}

H1: Awareness of the mobile banking services has a significant impact on rural bank customers to use the application.

H0: Awareness of the mobile banking services has no significant impact on rural bank customers to use the application

\begin{tabular}{|l|c|c|c|c|c|c|}
\hline Respondents & Observed & Expected & (O-E) & (O-E)2 & (O-E)2/E & Values \\
\hline Agree & 140 & 120 & 20 & 400 & $400 / 120$ & 3.33 \\
\hline Disagree & 70 & 80 & -10 & 100 & $100 / 80$ & 1.25 \\
\hline Neutral & 40 & 50 & -10 & 100 & $100 / 50$ & 2.00 \\
\hline
\end{tabular}

Calculated Value: 6.58; Degree of Freedom (n-1) i.e. 3-1=2

Table value of Chi-square test for 2 degree of freedom@5\% level of significance is 5.99 
Since the measured value is more than the tabulated value, null hypothesis is rejected. Therefore, alternative hypothesis is accepted. Therefore, knowledge of mobile banking services has a significant impact on customers of rural banks to use the application.

\section{FINDINGS}

The following are the key observations derived from the analysis of the data collected from the rural consumers in the District of Dehradun.

- $36 \%$ of the respondents were aware of Mobile banking services through Bank officials in the rural areas of Dehradun District.

- $\quad 92 \%$ of the respondents believe that mobile banking services are time saving and you need not be physically present in the bank premises to carry out banking transactions.

- $80 \%$ of the respondents felt that mobile banking services is very much convenient and $8 \%$ of the respondents felt that location of the rural customers is the factor that influence the mobile banking services in remote areas of Dehradun district.

- $\quad 80 \%$ of the respondents use mobile banking services for funds transfer and $64 \%$ of the respondents for online bill payments in the rural areas.

- $\quad 39 \%$ of the respondents use mobile banking services for online shopping and $40 \%$ of the respondents use for online banking transactions in Dehradun district.

- $56 \%$ of the respondents use mobile banking services because of the electronic payment system and quick settlement.

- $64 \%$ of the respondents frequently use of mobile banking services and only $4 \%$ of the respondent don't use mobile banking services.

- $44 \%$ of the respondents have felt that it is simple to operate and $20 \%$ of the respondents felt the they face difficultly in operating the banking services and need training for usage.

- $56 \%$ of the respondents are satisfied with the mobile banking services provided by rural banks in the dehradun district of Uttarakhand.

- $40 \%$ of the respondents faced the problems of internet connectivity speed in usage of Mobile banking services and $12 \%$ faced the problems of malware in the rural areas.

\section{CONCLUSIONS}

Mobile banking is a revolutionary device that is rapidly becoming a requirement. It is an effective financial tool for banks to stay profitable in today's unpredictable, dynamic marketplace. Most customers are indeed very satisfied with recent innovations in banking services. If attempts are taken to improve services and encourage new customers through numerous advertising campaigns, the demand for mobile banking will definitely grow in the future and new entrants will be able to penetrate the banking industry. Nowadays, customers seek more services. As a result, banks need to upgrade mobile banking services that will attract customers. 


\section{REFERENCES}

1. Ashta, A., \& Assadi, D. (2011). The use of Web 2.0 technologies in online lending and impact on different components of interest rates. In A. Ashta (Ed.), Advanced technologies for microfinance: Solutions and challenges (pp. 206-224). Hershey, $P A$ : Business Science Reference.

2. Asif, M., \& Krogstie, J. (2012). Research issues in personalization of mobile services. International Journal of Information Engineering and Electronic Business, 4(4), 1-8.

3. Au, Y. A., \& Kauffman, R. J. (2008). The economics of mobile payments: Understanding stakeholder issues for an emerging financial technology application. Electronic Commerce Research and Applications, 7, 141-164.

4. Austin, D., Barbir, A., Ferris, C., \& Garg, S. (Eds.). (2004). Web services architecture requirements, W3C Working Group Note, W3C. Retrieved from http://www.w3.org/TR/2004/NOTEwsa-reqs-20040211/

5. Avgerou, C. (2008). Information systems in developing countries: A critical research review. Journal of Information Technology, 23, 133-146.

6. Bagozzi, R. P. (2007). The legacy of the Technology Acceptance Model and a proposal for a paradigm shift. Journal of the Association for Information Systems, 8, 244-254.

7. Bashir, I. and Madhavaiah, C. (2015). Consumer attitude and behavioural intention towards Internet banking adoption in India. Journal of Indian Business Research, 7 (1), pp. 67 - 102.

8. Bhandani, A. K., Ravi Shankar D. and Rao, V. (2016). Modelling the factors and their interdependencies for investment decision in India mobile service sector. Journal of Modelling in Management, 11 (1), pp.1 - 25.

9. Chauhan, D. M. (2012). A Study on Customer Perception Towards Mobile Banking: Technology Adoption and Challenges. Indian Streams Research Journal, Vol. 2, No. 10, pp. 1-4.

10. Lisa Wessels and Judy Drennan (2010): “An investigation of consumer acceptance of Mobile banking”, International Journal of Bank Marketing, Vol. 28 No. 7, pp. 547-568

11. Mishra, S. K., \& Sahoo, D. P. (2013). Mobile Banking Adoption and Benefits Towards Customers Service. International Journal on Advanced Computer Theory and Engineering, Vol. 2, No. 1, pp. 78-83

12. S. Senthil Kumar and Dr. P. Abirami. (2017) Customer Usage Patterns and Satisfaction of E Banking Services. International Journal of Advanced Research in Management, 8(1), pp. 12-20.

13. Sowmya N, (2018) Sustainable E-Banking Challenges in Selected Manufacturing Industries in Mysuru City, International Journal of Mechanical Engineering and Technology 9(1), pp. 229-239.

14. Vidyapriya. P. and Mohanasundari. M(2015), "Customer Responsiveness on Banking Technology Products in Rural South India”, Asian Journal of Managerial Science, Vol. 4 No. 1, pp.27-32

15. Vijay m. kumbhar (August, 2011)," Scope and problems of Mobile banking solution for unbanked: a review of Indian economy “JBFSIR Volume 1, Issue 5 ISSN 2231-4288 
